\title{
T cell motility as modulator of interactions with dendritic cells
}

\author{
Jens V. Stein* \\ Theodor Kocher Institute, University of Bern, Bern, Switzerland
}

It is well established that the balance of costimulatory and inhibitory signals during interactions with dendritic cells (DCs) determines $T$ cell transition from a naive to an activated or tolerant/anergic status. Although many of these molecular interactions are well reproduced in reductionist in vitro assays, the highly dynamic motility of naive $T$ cells in lymphoid tissue acts as an additional lever to fine-tune their activation threshold. T cell detachment from DCs providing suboptimal stimulation allows them to search for DCs with higher levels of stimulatory signals, while storing a transient memory of short encounters. In turn, adhesion of weakly reactive $T$ cells to DCs presenting peptides presented on major histocompatibility complex with low affinity is prevented by lipid mediators. Finally, controlled recruitment of $\mathrm{CD}^{+}{ }^{+} \mathrm{T}$ cells to cognate $\mathrm{DC}-\mathrm{CD} 4^{+} \mathrm{T}$ cell clusters shapes memory $T$ cell formation and the quality of the immune response. Dynamic physiological lymphocyte motility therefore constitutes a mechanism to mitigate low avidity $T$ cell activation and to improve the search for "optimal" DCs, while contributing to peripheral tolerance induction in the absence of inflammation.

OPEN ACCESS

Edited by: Loï Dupré, INSERM, France

Reviewed by: Scott N. Mueller,

The University of Melbourne, Australia Emmanuel Donnadieu, INSERM, France

${ }^{*}$ Correspondence: Jens V. Stein jstein@tki.unibe.ch

Specialty section: This article was submitted to T Cell Biology, a section of the journal Frontiers in Immunology

Received: 10 August 2015 Accepted: 19 October 2015 Published: 02 November 2015

Citation:

Stein JV (2015) T cell motility as modulator of interactions with dendritic cells.

Front. Immunol. 6:559. doi: 10.3389/fimmu.2015.00559
Keywords: T cell motility, intravital imaging, thromboxane A2, T cell-DC interactions, Myo1g

\section{T LYMPHOCYTES ARE CELLS THAT SCAN THE SURFACES OF OTHER CELLS}

A defining feature of $\mathrm{T}$ cells is their ability to become activated by pathogen-derived peptides presented on major histocompatibility complexes (pMHCs), while remaining quiescent when selfpeptides are presented. Although in vitro experiments have successfully delineated the molecular requirements for TCR triggering and continue to serve as important experimental tool to analyze $\mathrm{T}$ cell activation, there is a factor that is difficult to reproduce in reductionist in vitro approaches: isolated naive $\mathrm{T}$ cells are typically immotile in vitro without prior activation, whereas these cells are remarkably motile in vivo. Direct observation of $\mathrm{T}$ cell behavior using intravital two photon microscopy (2PM) has shown that these cells have a polarized, amoeboid-like shape, and move in resting lymphoid tissue with speeds of $\sim 12-15 \mu \mathrm{m} / \mathrm{min}$, in an apparently random manner (1-5). Similarly, effector T cells in non-lymphoid tissues, including leptomeningeal membranes (6), liver (7), and pancreas (8), show continuous motility, although the tissue microarchitecture is likely to restrict T cell motility, in particular, in tightly packed epithelial layers of the skin (9). The dynamic motility has evolved because T cells are MHC restricted and therefore need to physically scan the surfaces of other cells. This process is balanced with rapid decision-making on whether to arrest (e.g., to exert cytotoxic activity against a target cell) or to continue migration. A central feature of $\mathrm{T}$ cell biology is therefore their ability to transit from a highly motile to a stationary phenotype, i.e., from vigorous scanning to firm adhesion. Decision-making of whether to "stop" or to "go" is probably most critical in lymphoid tissue, such as peripheral lymph nodes (PLNs), where T cells move with highest speeds and are therefore only in short contact with pMHC-presenting dendritic cells (DCs). 
In fact, it has been estimated that each DC is contacted by $\sim 500-5000$ T cells per hour, mostly for less than a few min (10, 11). This raises two questions: first, how is the $T$ cell motility induced in lymphoid tissue, and second, which factors influence T cell decision-making for fast arrest?

\section{REGULATION OF T CELL MOTILITY IN LYMPHOID TISSUE}

The PLN parenchyme consists of a sponge-like network of loosely spaced fibroblastic reticular cells (FRCs) expressing the promigratory chemokines CCL19 and CCL21, ligands for the CCR7 chemokine receptor present on naïve T cells (12). DCs are closely attached to the FRC network to facilitate their continuous scanning by T cells (13). Furthermore, the LFA-1 ligands ICAM-1 and ICAM-2 are expressed on both DCs and FRCs, while CCL21 is deposited on DCs $(14,15)$. 2PM imaging experiments have shown that CCR7 ligands and LFA-1-ICAM-1 interactions contribute to basal migration, although even in their absence, T cells retain their amoeboid migration mode and attain considerable average speeds of $\sim 10-12 \mu \mathrm{m} / \mathrm{min}(16-19)$. In line with these observations, $\mathrm{T}$ cells lacking the Goi2 subunit acting downstream of CCR7 move only slightly slower than WT T cells in PLN parenchyme (20). Chemokines and integrins induce $\mathrm{T}$ cell polarization and the formation of a leading edge and uropod as a result of multiple signaling cascades revised elsewhere (21-24). In brief, continuous Rac-mediated F-actin assembly at the leading edge, or lamellipodium, provides the protrusion force in $3 \mathrm{D}$ environments, even in the absence of integrin ligands (25). This is reflected in $\mathrm{T}$ cells lacking the DOCK2 guanine exchange factor for the small GTPase Rac1 and 2. These cells display strongly impaired in vitro motility (26), and similar to Rac1/2-double-deficient $\mathrm{T}$ cells, show virtually no residual migration in PLN parenchyme $(27,28)$. Thus, LFA-1, CCR7, and other, as of yet unknown factors lead to DOCK2-Rac-driven T cell motility. The importance of this pathway for host surveillance is underscored by the recent identification of DOCK2-deficient patients, who suffer from early onset severe invasive infections (29).

Furthermore, lysophosphatidic acid (LPA) produced by the exoenzyme autotaxin (ATX) on stromal cells, including high endothelial venules (HEVs) and FRCs, contributes to transmigration and basal lymphocyte motility in PLNs (30-34). LPA binds to T cell-expressed LPA2, a member of the GPCR family, and induces Rho activation, which cooperates with CCL21 to induce contractility-dependent lymphocyte migration. Pharmacological blocking of ATX or LPA receptors or lack of LPA2 reduces T cell speeds by $\sim 30 \%$ in vivo, while addition of LPA increases T cell polarization and speeds in vitro $(30,31,33)$. These observations are in line with recent descriptions of increased cell motility generated by augmented contractility of the trailing edge in confined environments $(35,36)$. Similarly, T cells crossing endothelial barriers is facilitated by the Rho-GTP effector ROCK and Myosin IIAmediated contractility to move the nucleus through narrow pores and for detachment of LFA-1-ICAM-1 adhesions $(25,37,38)$. Finally, in vitro and in vivo experiments support a role for tyrosine kinase signaling downstream chemokine receptor signaling in $\mathrm{T}$ cells. Thus, inhibition with Janus kinases (JAK) prevents $\mathrm{T}$ cell chemotaxis to CCL21, adhesion to HEVs and homing (39-41). Of note, interstitial motility within lymphoid tissue was not affected by the absence of JAK1 and JAK2, pointing to compensatory mechanisms that ensure robust motility.

\section{DYNAMIC CONTROL OF T CELL ARREST}

Ground-breaking work by Dustin and colleagues has uncovered that in vitro generated chemotactic gradients, including the prototypic T cell-attracting chemokine CCL21, are capable to disrupt TCR-pMHC complexes, leading to detachment from antigenpresenting cells and blunted T cell activation $(42,43)$. Although CCL21 gradients have been confirmed in interfollicular regions of PLNs (44), it remains unclear whether such gradients exist in the paracortical $\mathrm{T}$ cell zone or around HEVs, where naive T cells first encounter DCs (45). Interestingly, mice lacking promigratory CCR7 ligands show a delayed but ultimately enhanced $\mathrm{T}$ cell responses during immune responses (46). The delayed onset may result from lack of efficient T cell-DC encounters at early time points, while exceeding $\mathrm{T}$ cell responses at later time points are consistent with an immunosuppressive action of CCL21 via disruption of weakly reactive T cell - DC interactions.

Two photon microscopy analysis has helped to subdivide $\mathrm{T}$ cell-DC interactions into distinct phases that are regulated by surface levels of pMHC on DCs, as well as the TCR-pMHC affinity. Thus, high levels of cognate $\mathrm{pMHC}$ are able to induce immediate arrest of reactive $\mathrm{T}$ cells, whereas low levels result in a continuous scanning behavior of T cells (47-49). During scanning, which can last up to $8 \mathrm{~h}$ and is referred to as "phase 1," T cells are able to summate signals through active NFAT and c-fos signaling $(50,51)$. In addition to pMHC, ICAM-1 on DCs facilitates T cell arrest (52), whereas regulatory $\mathrm{T}$ cells (Tregs) prevent stable interactions with DCs in this phase $(53,54)$. "Phase 2 " stable T cell-DC interactions last for several hours and are commonly thought to be critical for full $\mathrm{T}$ cell activation through the formation of an immunological synapse (IS). Thus far, the precise duration of individual stable T cell-DC contacts has proven difficult to assess in vivo, owing to technical limitations maintaining physiological conditions and the identical field of view during intravital imaging. After $\sim 20 \mathrm{~h}$ post $\mathrm{T}$ cell transfer, activated $\mathrm{T}$ cells resume motility and detach from DCs before committing to cell division, in the so-called phase 3 (Figure 1A).

Early in vitro evidence suggests that decision-making leading to arrest on DCs may require only a few seconds and correlates with induction of Ca flux in responsive $\mathrm{T}$ cells $(56,57)$. Interestingly, dynamic DOCK2-driven F-actin assembly at the leading edge of motile T cells is maintained during interactions with DCs, but with a different spatial arrangement at the IS interface. TCR signaling and ICAM-1-LFA-1-mediated adhesion convert Rac-driven protrusion activity at the lamellipodium of migrating $\mathrm{T}$ cells into an annular F-actin ring with centripetal directionality at the IS interface $(58,59)$. Combining these in vitro observations with 2PM data, the decision-making of motile T cells to undergo conversion from translocation to arrest requires a threshold pMHC level on DCs, sufficient integrated signals from previous DC encounters and LFA-1-mediated firm adhesion. Weak activatory signals because of low pMHC levels, low TCR-pMHC affinity or 


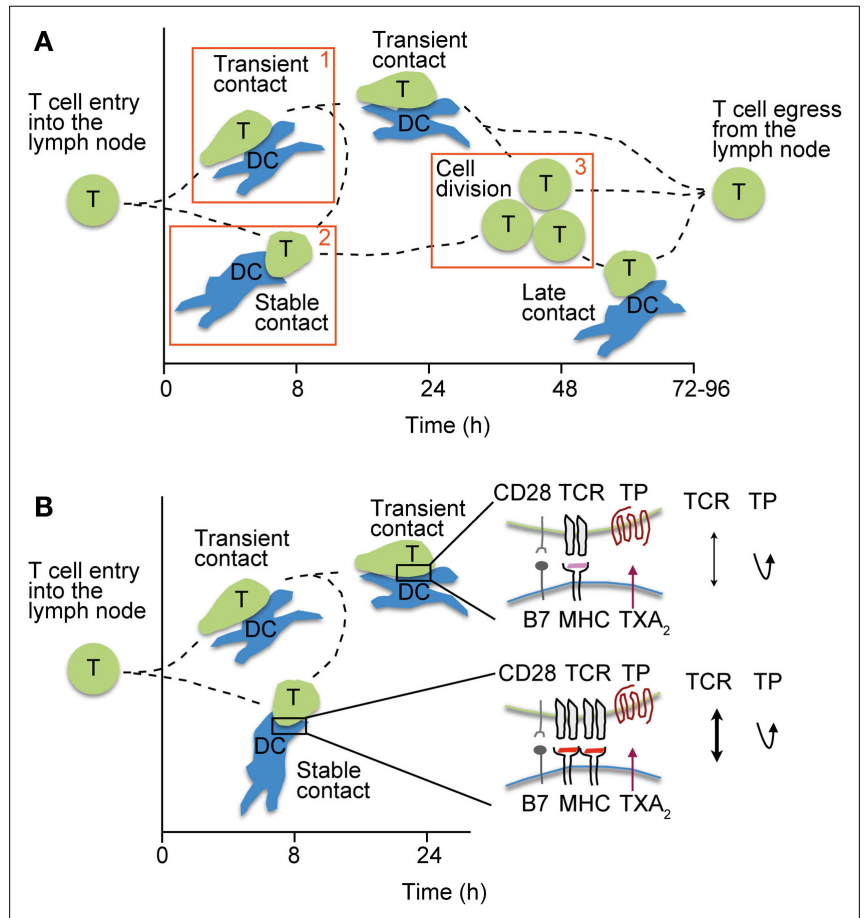

C

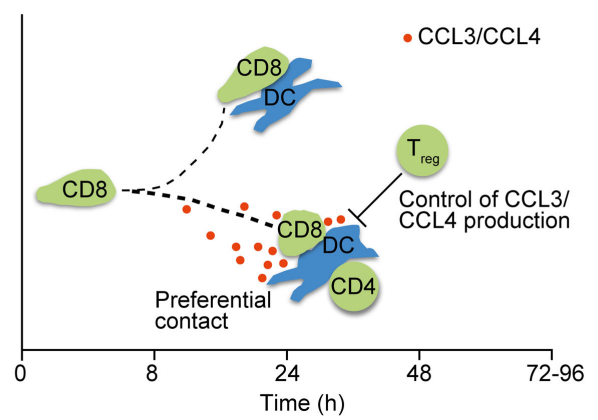

FIGURE 1 | Motile T cell-DC interactions in lymphoid tissue. (A) Phases of interactions between pMHC-loaded DCs and T cells after their entry into lymph nodes. Phase 1 is characterized by transient interactions, whereas $T$ cells engage stably with DCs during phase 2 . In phase 3 , T cells detach from DCs and begin to divide before egressing as effector $\mathrm{T}$ cells. Adapted from Ref. (55). (B) Regulation of weak T cell-DC interactions by TXA2 secretion. TP-induced motility prevents stable T cell attachment (phase 1-2 transition) unless a critical pMHC threshold is presented on DCs, thus ensuring a high quality of ensuing $\mathrm{CD} 4^{+} \mathrm{T}$ cell responses. (C) Secretion of CCR5 ligands CCL3 and CCL4 by pairs of interacting CD4 ${ }^{+} T$ cells and DCs attract naïve $\mathrm{CD}^{+}{ }^{+}$cells and helps to foster $\mathrm{CD} 4^{+} \mathrm{T}$ cell help. By contrast, excessive CCR5 ligand production in the absence of Tregs deteriorates the quality of $\mathrm{CD}^{+} \mathrm{T}$ cell responses by allowing weakly interacting clones to attach to $\mathrm{DCs}$.

lack of ICAM-1 on DCs would be insufficient to trigger F-actin conversion to a ring-like structure. Consistent with this model, inhibitory receptors of TCR signaling including CTLA-4 and PD1 prevent $\mathrm{T}$ cell adhesion to antigen-presenting cells (60-62).

Recent work by Krummel and colleagues has shown that naïve $\mathrm{T}$ cells express Myolg, a regulator of membrane tension. When $\mathrm{T}$ cells are exposed to physical pressure, Myo1g accumulates at the spot of pressure exertion, followed by adjacent generation of a newly formed F-actin protrusion (63). In vitro and in vivo assays uncovered that Myolg activity results in a meandering migration pattern, since Myolg-deficient $\mathrm{T}$ cells showed less turning behavior and higher directionality. As a result, Myolg-deficient T cells displayed shorter interaction times with DCs in vivo, as the average scanning time decreased from $\sim 1.7$ to $1 \mathrm{~min}$. This reduced interaction time had a significant impact for $\mathrm{T}$ cell engagement with rare DCs, since Myolg-deficient T cells were unable to "read" enough DC activation signals for arrest conversion and maintained their migratory behavior (63). In sum, in vivo migrating $\mathrm{T}$ cells need a minimal DC scanning time of $\sim 100 \mathrm{~s}$ to integrate sufficient TCR signals for a successful conversion of protruding to annular F-actin and IS formation. This process is supported by LFA-1 adhesion to ICAM-1 on DCs.

\section{THROMBOXANE A2-INDUCED MOTILITY AS QUALITY CONTROL FOR CD4 ${ }^{+}$T CELL RESPONSES}

Activated DCs increase surface expression of costimulatory molecules and are therefore able to efficiently activate $\mathrm{T}$ cells, including weakly reactive or potentially self-reactive clones. Work by Sanui and colleagues has identified activated DCs and macrophages as important source of thromboxane A2 (TXA2). TXA2 is a secreted lipid with short half-life that binds the Go12/13-coupled TP receptor expressed on naïve but not effector/memory T cells. Binding of TXA2 to TP induces lsc (also known as p115 RhoGEF or ArhGEF1)-mediated Rho activation (64), which induces chemokinetic motility in vitro and disruption of T cell-DC pairs (65). In a recent study, TXA2 was shown to specifically thwart the activation of weakly reactive $\mathrm{CD} 4^{+} \mathrm{T}$ cell clones. After immunization or infection, Ag-specific $\mathrm{CD} 4^{+}$ $\mathrm{T}$ cells that bound tetramers only weakly expanded significantly more in the absence of TP. Using 2PM imaging of reactive PLNs, the absence of $\mathrm{TP}$ on naive $\mathrm{CD} 4^{+} \mathrm{T}$ cells resulted in increased interactions with DCs presenting low amounts or weak agonist pMHC, leading to a premature phase 1 to phase 2 transition and excessive T cell expansion (Figure 1B). By contrast, WT- and TPdeficient $\mathrm{CD} 4^{+} \mathrm{T}$ cells similarly engaged with DCs presenting high amounts of agonist pMHC, indicating that TXA2 preferentially prevents arrest of weakly reactive $\mathrm{T}$ cell clones (66). Thus, TXA2 allows T cells to maintain their search for DCs presenting high levels of cognate $\mathrm{pMHC}$, rather than weak agonist or self-peptides. Indeed, TXA2-mediated quality control of early T cell-DC interactions prevented the excessive generation of follicular helper cells, which provide help to weakly reactive germinal center B cells. As consequence, lack of TXA2-TP signaling during $\mathrm{T}$ cell priming deteriorated the overall quality of the ensuing immune response (66).

\section{TIGHTLY REGULATED CCR5 LIGAND EXPRESSION CONTROLS THE QUALITY OF CD8 ${ }^{+} \mathrm{T}$ CELL RESPONSES}

A comparable link between the quality of adaptive immune responses and low affinity-driven interactions was made when examining how the absence of Tregs affected $\mathrm{CD}^{+} \mathrm{T}$ cell engagement with DCs. Previous work had shown that baseline 
production of CCR5 ligands CCL3 and CCL4 leads to the recruitment of naive $\mathrm{CD} 8^{+} \mathrm{T}$ cells to $\mathrm{DC}$ engaged in productive interactions with $\mathrm{CD} 4^{+} \mathrm{T}$ cells, resulting in $\mathrm{CD} 4^{+} \mathrm{T}$ cell help and effective $\mathrm{CD}^{+} \mathrm{T}$ cell memory formation (67). By contrast, in the absence of Tregs, DCs produced increased amounts of CCR5 ligands that facilitated excessive engagement of $\mathrm{CD}^{+}$ $\mathrm{T}$ cells with DCs presenting low-affinity pMHC complexes as assessed by 2PM imaging (Figure 1C). This resulted in an overall lower quality of the adaptive immune responses, since the ratio of low versus high avidity clones was shifted towards the former population (68). Thus, similar to TXA2, motility-inducing agents influence $\mathrm{T}$ cell-DC interactions inside reactive PLNs that contain highly stimulatory DCs. It is interesting to note that in non-reactive PLNs, the absence of CCR5 ligand production and TXA2 permits unbiased scanning of resident DCs by naïve $\mathrm{T}$ cells, which is essential for efficient peripheral tolerance education.

\section{CONCLUDING REMARKS}

Two photon microscopy-based investigation of T cell-DC interactions has uncovered factors that, in addition to pMHC abundance and affinity, regulate the dynamic interplay between these two cell types. Although tightly regulated $\mathrm{T}$ cell attraction to activated DCs promote adaptive immune responses by allowing rare cells to meet, excessive interactions with low-affinity $\mathrm{pMHC}$ presenting DCs deteriorate the overall quality of clonal expansion.

\section{REFERENCES}

1. Wei SH, Parker I, Miller MJ, Cahalan MD. A stochastic view of lymphocyte motility and trafficking within the lymph node. Immunol Rev (2003) 195:136-59. doi:10.1034/j.1600-065X.2003.00076.x

2. Germain R, Miller M, Dustin M, Nussenzweig M. Dynamic imaging of the immune system: progress, pitfalls and promise. Nat Rev Immunol (2006) 6:497-507. doi:10.1038/nri1884

3. Sumen C, Mempel TR, Mazo IB, Andrian Von UH. Intravital microscopy: visualizing immunity in context. Immunity (2004) 21:315-29. doi:10.1016/j. immuni.2004.08.006

4. Breart B, Bousso P. Cellular orchestration of $\mathrm{T}$ cell priming in lymph nodes. Curr Opin Immunol (2006) 18:483-90. doi:10.1016/j.coi.2006.05.006

5. Friedl P, Weigelin B. Interstitial leukocyte migration and immune function. Nat Immunol (2008) 9:960-9. doi:10.1038/ni.f.212

6. Bartholomäus I, Kawakami N, Odoardi F, Schläger C, Miljkovic D, Ellwart JW, et al. Effector $\mathrm{T}$ cell interactions with meningeal vascular structures in nascent autoimmune CNS lesions. Nature (2009) 462:94-8. doi:10.1038/ nature 08478

7. Guidotti LG, Inverso D, Sironi L, Di Lucia P, Fioravanti J, Ganzer L, et al. Immunosurveillance of the liver by intravascular effector CD8+ T Cells. Cell (2015) 161:486-500. doi:10.1016/j.cell.2015.03.005

8. Coppieters K, Amirian N, Herrath von M. Intravital imaging of CTLs killing islet cells in diabetic mice. J Clin Invest (2012) 122:119-31. doi:10.1172/ JCI59285

9. Gebhardt T, Whitney PG, Zaid A, Mackay LK, Brooks AG, Heath WR, et al. Different patterns of peripheral migration by memory CD4+ and CD8+ T cells. Nature (2011) 477:216-9. doi:10.1038/nature10339

10. Bousso P, Robey E. Dynamics of CD8+ T cell priming by dendritic cells in intact lymph nodes. Nat Immunol (2003) 4:579-85. doi:10.1038/ni928

11. Miller MJ, Hejazi AS, Wei SH, Cahalan MD, Parker I. T cell repertoire scanning is promoted by dynamic dendritic cell behavior and random $\mathrm{T}$ cell motility in the lymph node. Proc Natl Acad Sci U S A (2004) 101:998-1003. doi:10.1073/ pnas.0306407101
Furthermore, intrinsic wiring of the migratory behavior of T cells facilitates their scanning function. Thus, programmed Myolginduced meandering behavior permits sufficiently long interactions between $\mathrm{T}$ cells and DCs. In addition, continuous F-actin treadmilling during both migration and IS formation endows $\mathrm{T}$ cells with the capacity to quickly switch between migratory versus stationary modes. Thus, upon cessation of TCR signaling, $\mathrm{T}$ cells resume their motility, presumably to avoid overstimulation and to prepare for egress. These observations raise new interesting questions. For example, is the duration of phase 2-like stable interactions regulated by external chemoattractant gradients or cell-intrinsic mechanisms? Furthermore, desensitization of chemokine receptors, such as CCR5, and its impact on T cell motility patterns in vivo has not been investigated in detail. Such studies are relevant since CCR5 ligands attract cognate and noncognate naïve $\mathrm{CD} 8^{+} \mathrm{T}$ cells, and would rapidly limit access to DCs unless CCR5 desensitization is allowing cell turnover. The continued examination of mechanisms that control T cell motility in lymphoid tissue and their impact on adaptive immune responses will remain a productive field of research in years to come.

\section{ACKNOWLEDGMENTS}

The Stein laboratory is funded by Swiss National Foundation grants 31003A_135649, CR23I3_156234, and CRSII3_141918, FP7 Marie Curie RG grant 276702, and Swiss Cancer League grant KFS-3524-08-2014.

12. Bajénoff M, Egen JG, Qi H, Huang AYC, Castellino F, Germain RN. Highways, byways and breadcrumbs: directing lymphocyte traffic in the lymph node. Trends Immunol (2007) 28:346-52. doi:10.1016/j.it.2007.06.005

13. Katakai T, Habiro K, Kinashi T. Dendritic cells regulate high-speed interstitial $\mathrm{T}$ cell migration in the lymph node via LFA-1/ICAM-1. J Immunol (2013) 191:1188-1199. doi:10.4049/jimmunol.1300739

14. Boscacci RT, Pfeiffer F, Gollmer K, Sevilla AIC, Martin AM, Soriano SF, et al. Comprehensive analysis of lymph node stroma-expressed Ig superfamily members reveals redundant and nonredundant roles for ICAM-1, ICAM-2, and VCAM-1 in lymphocyte homing. Blood (2010) 116:915-25. doi:10.1182/blood2009-11-254334

15. Wendland M, Willenzon S, Kocks J, Davalos-Misslitz AC, Hammerschmidt SI, Schumann K, et al. Lymph node T cell homeostasis relies on steady state homing of dendritic cells. Immunity (2011) 35:945-57. doi:10.1016/j.immuni. 2011.10.017

16. Okada T, Cyster J. CC chemokine receptor 7 contributes to Gi-dependent T cell motility in the lymph node. J Immunol (2007) 178:2973. doi:10.4049/jimmunol. 178.5.2973

17. Worbs T, Mempel TR, Bölter J, Andrian Von UH, Förster R. CCR7 ligands stimulate the intranodal motility of T lymphocytes in vivo. J Exp Med (2007) 204:489-95. doi:10.1084/jem.20061706

18. Asperti-Boursin F, Real E, Bismuth G, Trautmann A, Donnadieu E. CCR7 ligands control basal $\mathrm{T}$ cell motility within lymph node slices in a phosphoinositide 3-kinase-independent manner. J Exp Med (2007) 204:1167-79. doi:10.1084/ jem.20062079

19. Woolf E, Grigorova I, Sagiv A, Grabovsky V, Feigelson SW, Shulman Z, et al. Lymph node chemokines promote sustained $\mathrm{T}$ lymphocyte motility without triggering stable integrin adhesiveness in the absence of shear forces. Nat Immunol (2007) 8:1076-85. doi:10.1038/ni1499

20. Hwang I, Park C, Kehrl J. Impaired trafficking of Gnai2 \pm and Gnai2-/-T lymphocytes: implications for $\mathrm{T}$ cell movement within lymph nodes. J Immunol (2007) 179:439. doi:10.4049/jimmunol.179.1.439

21. Krummel MF, Macara I. Maintenance and modulation of T cell polarity. Nat Immunol (2006) 7:1143-9. doi:10.1038/ni1404 
22. Thelen M, Stein J. How chemokines invite leukocytes to dance. Nat Immunol (2008) 9:953-9. doi:10.1038/ni.f.207

23. Ley K, Laudanna C, Cybulsky MI, Nourshargh S. Getting to the site of inflammation: the leukocyte adhesion cascade updated. Nat Rev Immunol (2007) 7:678-89. doi: $10.1038 /$ nri2156

24. Niggli V. Insights into the mechanism for dictating polarity in migrating Tcells. Int Rev Cell Mol Biol (2014) 312:201-70. doi:10.1016/B978-0-12-8001783.00007-5

25. Lämmermann T, Bader BL, Monkley SJ, Worbs T, Wedlich-Söldner R, Hirsch K, et al. Rapid leukocyte migration by integrin-independent flowing and squeezing. Nature (2008) 453:51-5. doi:10.1038/nature06887

26. Fukui Y, Hashimoto O, Sanui T, Oono T, Koga H, Abe M, et al. Haematopoietic cell-specific CDM family protein DOCK2 is essential for lymphocyte migration. Nature (2001) 412:826-31. doi:10.1038/35090591

27. Nombela-Arrieta C, Mempel TR, Soriano SF, Mazo I, Wymann MP, Hirsch E, et al. A central role for DOCK2 during interstitial lymphocyte motility and sphingosine-1-phosphate-mediated egress. J Exp Med (2007) 204:497-510. doi:10.1084/jem.20061780

28. Faroudi M, Hons M, Zachacz A, Dumont C, Lyck R, Stein JV, et al. Critical roles for Rac GTPases in T-cell migration to and within lymph nodes. Blood (2010) 116:5536-47. doi:10.1182/blood-2010-08-299438

29. Dobbs K, Domínguez Conde C, Zhang S-Y, Parolini S, Audry M, Chou J, et al. Inherited DOCK2 deficiency in patients with early-onset invasive infections. $N$ Engl J Med (2015) 372:2409-22. doi:10.1056/NEJMoa1413462

30. Katakai T, Kondo N, Ueda Y, Kinashi T. Autotaxin produced by stromal cells promotes LFA-1-independent and Rho-dependent interstitial T cell motility in the lymph node paracortex. J Immunol (2014) 193:617-26. doi:10.4049/ jimmunol.1400565

31. Knowlden SA, Capece T, Popovic M, Chapman TJ, Rezaee F, Kim M, et al. Regulation of T cell motility in vitro and in vivo by LPA and LPA2. PLoS One (2014) 9:e101655. doi:10.1371/journal.pone.0101655

32. Bai Z, Cai L, Umemoto E, Takeda A, Tohya K, Komai Y, et al. Constitutive lymphocyte transmigration across the basal lamina of high endothelial venules is regulated by the autotaxin/lysophosphatidic acid axis. J Immunol (2013) 190:2036-48. doi:10.4049/jimmunol.1202025

33. Zhang Y, Chen Y-CM, Krummel MF, Rosen SD. Autotaxin through lysophosphatidic acid stimulates polarization, motility, and transendothelial migration of naive T cells. J Immunol (2012) 189:3914-24. doi:10.4049/ jimmunol.1201604

34. Kanda H, Newton R, Klein R, Morita Y, Gunn MD, Rosen SD. Autotaxin, an ectoenzyme that produces lysophosphatidic acid, promotes the entry of lymphocytes into secondary lymphoid organs. Nat Immunol (2008) 9:415-23. doi:10.1038/ni1573

35. Liu Y-J, Le Berre M, Lautenschlaeger F, Maiuri P, Callan-Jones A, Heuzé M, et al. Confinement and low adhesion induce fast amoeboid migration of slow mesenchymal cells. Cell (2015) 160:659-72. doi:10.1016/j.cell.2015.01.007

36. Ruprecht V, Wieser S, Callan-Jones A, Smutny M, Morita H, Sako K, et al. Cortical contractility triggers a stochastic switch to fast amoeboid cell motility. Cell (2015) 160:673-85. doi:10.1016/j.cell.2015.01.008

37. Jacobelli J, Estin Matthews M, Chen S, Krummel MF. Activated T cell transendothelial migration relies on myosin-IIA contractility for squeezing the cell nucleus through endothelial cell barriers. PLoS One (2013) 8:e75151. doi:10. 1371/journal.pone.0075151

38. Soriano SF, Hons M, Schumann K, Kumar V, Dennier TJ, Lyck R, et al. In vivo analysis of uropod function during physiological $\mathrm{T}$ cell trafficking. J Immunol (2011) 187:2356-64. doi:10.4049/jimmunol.1100935

39. Pérez-Rivero G, Cascio G, Soriano SF, Sanz ÁG, de Guinoa JS, Rodríguez-Frade $\mathrm{JM}$, et al. Janus kinases 1 and 2 regulate chemokine-mediated integrin activation and naïve T-cell homing. Eur J Immunol (2013) 43:1745-57. doi:10.1002/eji. 201243178

40. Stein JV, Soriano SF, M'rini C, Nombela-Arrieta C, de Buitrago GG, RodríguezFrade JM, et al. CCR7-mediated physiological lymphocyte homing involves activation of a tyrosine kinase pathway. Blood (2003) 101:38-44. doi:10.1182/ blood-2002-03-0841

41. Montresor A, Bolomini-Vittori M, Toffali L, Rossi B, Constantin G, Laudanna C. JAK tyrosine kinases promote hierarchical activation of Rho and Rap modules of integrin activation. J Cell Biol (2013) 203:1003-19. doi:10.1083/jcb. 201303067
42. Bromley SK, Peterson DA, Gunn MD, Dustin ML. Cutting edge: hierarchy of chemokine receptor and TCR signals regulating $\mathrm{T}$ cell migration and proliferation. J Immunol (2000) 165:15-9. doi:10.4049/jimmunol.165.1.15

43. Dustin ML. Stop and go traffic to tune T cell responses. Immunity (2004) 21:305-14. doi:10.1016/j.immuni.2004.08.016

44. Ulvmar MH, Werth K, Braun A, Kelay P, Hub E, Eller K, et al. The atypical chemokine receptor CCRL1 shapes functional CCL21 gradients in lymph nodes. Nat Immunol (2014) 15:623-30. doi:10.1038/ni.2889

45. Bajenoff M, Granjeaud S, Guerder S. The strategy of T cell antigen-presenting cell encounter in antigen-draining lymph nodes revealed by imaging of initial T cell activation. J Exp Med (2003) 198:715-24. doi:10.1084/jem.20030167

46. Mori S, Nakano H, Aritomi K, Wang C, Gunn M, Kakiuchi T. Mice lacking expression of the chemokines CCL21-ser and CCL19 (plt mice) demonstrate delayed but enhanced T cell immune responses. J Exp Med (2001) 193:207. doi:10.1084/jem.193.2.207

47. Mempel TR, Henrickson SE, Andrian Von UH. T-cell priming by dendritic cells in lymph nodes occurs in three distinct phases. Nature (2004) 427:154-9. doi:10.1038/nature02238

48. Henrickson SE, Mempel TR, Mazo IB, Liu B, Artyomov MN, Zheng H, et al. $\mathrm{T}$ cell sensing of antigen dose governs interactive behavior with dendritic cells and sets a threshold for T cell activation. Nat Immunol (2008) 9:282-91. doi:10. 1038/ni1559

49. Henrickson SE, Perro M, Loughhead SM, Senman B, Stutte S, Quigley M, et al. Antigen availability determines CD8+ T cell-dendritic cell interaction kinetics and memory fate decisions. Immunity (2013) 39:496-507. doi:10.1016/ j.immuni.2013.08.034

50. Clark CE, Hasan M, Bousso P. A role for the immediate early gene product c-fos in imprinting T cells with short-term memory for signal summation. PLoS One (2011) 6:e18916. doi:10.1371/journal.pone.0018916

51. Marangoni F, Murooka TT, Manzo T, Kim EY, Carrizosa E, Elpek NM, et al. The transcription factor NFAT exhibits signal memory during serial $\mathrm{T}$ cell interactions with antigen-presenting cells. Immunity (2013) 38:237-49. doi:10. 1016/j.immuni.2012.09.012

52. Scholer A, Hugues S, Boissonnas A, Fetler L, Amigorena S. Intercellular adhesion molecule-1-dependent stable interactions between $\mathrm{T}$ cells and dendritic cells determine CD8+ T cell memory. Immunity (2008) 28:258-70. doi:10.1016/ j.immuni.2007.12.016

53. Tadokoro CE, Shakhar G, Shen S, Ding Y, Lino AC, Maraver A, et al. Regulatory $\mathrm{T}$ cells inhibit stable contacts between $\mathrm{CD} 4+\mathrm{T}$ cells and dendritic cells in vivo. J Exp Med (2006) 203:505-11. doi:10.1084/jem.20050783

54. Tang Q, Adams JY, Tooley AJ, Bi M, Fife BT, Serra P, et al. Visualizing regulatory $\mathrm{T}$ cell control of autoimmune responses in nonobese diabetic mice. Nat Immunol (2006) 7:83-92. doi:10.1038/ni1289

55. Bousso P. T-cell activation by dendritic cells in the lymph node: lessons from the movies. Nat Rev Immunol (2008) 8:675-84. doi:10.1038/nri2379

56. Donnadieu E, Bismuth G, Trautmann A. Antigen recognition by helper T cells elicits a sequence of distinct changes of their shape and intracellular calcium. Curr Biol (1994) 4:584-95. doi:10.1016/S0960-9822(00)00130-5

57. Negulescu PA, Krasieva TB, Khan A, Kerschbaum HH, Cahalan MD. Polarity of T cell shape, motility, and sensitivity to antigen. Immunity (1996) 4:421-30. doi:10.1016/S1074-7613(00)80409-4

58. Grakoui A, Bromley SK, Sumen C, Davis MM, Shaw AS, Allen PM, et al. The immunological synapse: a molecular machine controlling $\mathrm{T}$ cell activation. Science (1999) 285:221-7. doi:10.1126/science.285.5425.221

59. Le Floc'h A, Tanaka Y, Bantilan NS, Voisinne G, Altan-Bonnet G, Fukui Y, et al. Annular PIP3 accumulation controls actin architecture and modulates cytotoxicity at the immunological synapse. J Exp Med (2013) 210:2721-37. doi:10.1016/j.cub.2005.12.024

60. Schneider H, Downey J, Smith A, Zinselmeyer BH, Rush C, Brewer JM, et al. Reversal of the TCR stop signal by CTLA-4. Science (2006) 313:1972-5. doi:10. 1126/science. 1131078

61. Fife BT, Pauken KE, Eagar TN, Obu T, Wu J, Tang Q, et al. Interactions between PD-1 and PD-L1 promote tolerance by blocking the TCR-induced stop signal. Nat Immunol (2009) 10:1185-92. doi:10.1038/ni.1790

62. Honda T, Egen JG, Lämmermann T, Kastenmuller W, Torabi-Parizi P, Germain RN. Tuning of antigen sensitivity by $\mathrm{T}$ cell receptor-dependent negative feedback controls T cell effector function in inflamed tissues. Immunity (2014) 40:235-47. doi:10.1016/j.immuni.2013.11.017 
63. Gérard A, Patiño-López G, Beemiller P, Nambiar R, Ben-Aissa K, Liu Y, et al. Detection of rare antigen-presenting cells through $\mathrm{T}$ cell-intrinsic meandering motility, mediated by Myolg. Cell (2014) 158:492-505. doi:10.1016/j.cell.2014. 05.044

64. Harenberg A, Girkontaite I, Giehl K, Fischer K-D. The Lsc RhoGEF mediates signaling from thromboxane A2 to actin polymerization and apoptosis in thymocytes. Eur J Immunol (2005) 35:1977-86. doi:10.1002/eji.200425769

65. Kabashima K, Murata T, Tanaka H, Matsuoka T, Sakata D, Yoshida N, et al. Thromboxane A2 modulates interaction of dendritic cells and T cells and regulates acquired immunity. Nat Immunol (2003) 4:694-701. doi:10.1038/ni943

66. Moalli F, Cupovic J, Thelen F, Halbherr P, Fukui Y, Narumiya S, et al. Thromboxane A2 acts as tonic immunoregulator by preferential disruption of lowavidity CD4+ T cell-dendritic cell interactions. J Exp Med (2014) 211:2507-17. doi:10.1084/jem.20140137

67. Castellino F, Huang AY, Altan-Bonnet G, Stoll S, Scheinecker C, Germain $\mathrm{RN}$. Chemokines enhance immunity by guiding naive CD8+ T cells to sites of
CD4+ T cell-dendritic cell interaction. Nature (2006) 440:890-5. doi:10.1038/ nature 04651

68. Pace L, Tempez A, Arnold-Schrauf C, Lemaitre F, Bousso P, Fetler L, et al. Regulatory $\mathrm{T}$ cells increase the avidity of primary CD8+ T cell responses and promote memory. Science (2012) 338:532-6. doi:10.1126/science.1227049

Conflict of Interest Statement: The author declares that the research was conducted in the absence of any commercial or financial relationships that could be construed as a potential conflict of interest.

Copyright (C) 2015 Stein. This is an open-access article distributed under the terms of the Creative Commons Attribution License (CC BY). The use, distribution or reproduction in other forums is permitted, provided the original author(s) or licensor are credited and that the original publication in this journal is cited, in accordance with accepted academic practice. No use, distribution or reproduction is permitted which does not comply with these terms. 